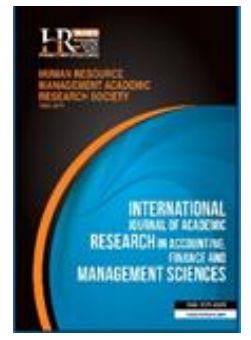

International Journal of Academic Research in Accounting, Finance and Management Sciences

Vol. 9, No.1, January 2019, pp. 30-41

E-ISSN: 2225-8329, P-ISSN: 2308-0337

(C) 2018 HRMARS

www.hrmars.com

To cite this article: Alshira'h A. F., Abdul-Jabbar, H., Samsudin, R. S. (2019). The Effect of Tax Moral on Sales Tax Compliance among Jordanian SMES, International Journal of Academic Research in Accounting, Finance and Management Sciences 9 (1): 30-41

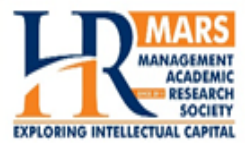

http://dx.doi.org/10.6007/IJARAFMS/v9-i1/5722 (DOI: 10.6007/IJARAFMS/v9-i1/5722)

\title{
The Effect of Tax Moral on Sales Tax Compliance among Jordanian SMEs
}

\section{Ahmad Farhan Alshira'h' ${ }^{1}$, Hijattulah Abdul-Jabbar², Rose Shamsiah Samsudin ${ }^{3}$}

\author{
Faculty of Finance and Business Administration, Al al-Bayt University, Jordan, \\ ${ }^{1}$ E-mail: Alshraah.ahmad@yahoo.com (Corresponding author) \\ ${ }^{2,3}$ Tunku Puteri Intan Safinaz School of Accountancy, Universiti Utara Malaysia
}

\begin{abstract}
The current paper examines the relation between tax moral and the sales tax compliance of SMEs. The impact of tax moral on sales tax compliance has been received a very little attention. However, to date, there has been no work on the effect of tax moral on sales tax compliance among Jordanian SMEs. This relationship was then tested based on the survey outcomes from 212 SMEs serving in Jordan. The Partial Least Squares (PLS) results revealed positive influence of tax moral on sales tax compliance. Besides extending the body of knowledge by providing a model to explain how tax moral influence sales tax compliance, the results offer insights on the tax moral of sales tax compliance among SMEs. This study also highlights the implications of this finding towards the owner-managers of SMEs and the potential future research.

Key words Tax moral, sales tax compliance, SMEs

Received: 30 Mar $2019 \quad$ (c) The Authors 2019

Revised: 20 Apr 2019 Published by Human Resource Management Academic Research Society (www.hrmars.com)

Accepted: 25 Apr 2019 This article is published under the Creative Commons Attribution (CC BY 4.0) license. Anyone may Published Online: 18 reproduce, distribute, translate and create derivative works of this article (for both commercial and non-commercial purposes), subject to full attribution to the original publication and authors. The full terms of this license may be seen at: http://creativecommons.org/licences/by/4.0/legalcode
\end{abstract}

\section{Introduction}

This study extends the literatures on tax compliance by examining the impact of tax moral on sales tax compliance in the context of SMEs. Previous work, such as Pope and Abdul-Jabbar (2008) indicated that the taxation of SMEs has attracted increasing interest in the last decade in developing and developed states alike, SMEs around the globe are characterized by tax non-compliant entities. Arachi and Santoro (2007) suggested that SMEs are considered to be the main contributors of income in the shadow economy in developing countries. Hence, Swistak (2015) indicated that the tax compliance of SMEs requires special interest, so that the issue of an overwhelming number of SMEs being unable to fulfilling their tax compliance can be addressed.

The majority of countries in the world develop their country mainly from tax sources (Palil, 2005). Taxes are essential elements of any attempt to build nations (Young et al., 2016). Therefore, governments should have sufficient revenue to finance infrastructure, social services and ensure adequate provision of services (Ndekwa, 2014). Thus, taxation has become increasingly important for the countries. Tax revenue collection has become a significant issue, particularly after the world economic crisis of 2008, the increasing public fiscal deficit of states has raised the need for tax revenue considerably, and states have turned toward universal collaboration to combat tax non-compliance (Obara and Nangih, 2017; Obadina, 2016; Nar, 2015; Sawyer, 2014). In other words, tax compliance leads to reducing the fiscal deficit and public 
debt, thereby it provides funding to satisfy the economic and social development (Alshira'h and AbdulJabbar, 2019a).

Consistent with this, prior research agreed that tax non-compliance is a serious and growing problem in all economies and societies in both developing and developed countries (Awang et al., 2018; Alasfour, 2017; Alm et al., 2016; Raza and Naqvi, 2016). Tax non-compliance is a huge problem and a master challenge that is prevalent in developing states (Asrinanda, 2018; Rosid et al., 2017; Al-Ttaffi and AbdulJabbar, 2015). Yet in spite of being a critical issue for developing countries, tax compliance has obtained little attention in the empirical evidence (Gangl et al., 2015), which demands that the problems be addressed from various perspectives (Finocchiaro and Ilde, 2014), therefore, encouraging many to conduct studies on tax compliance matters (Abdul-Jabbar and Pope, 2008). Yet, there is no consensus on what precisely influences the willingness to pay taxes (Randlane, 2016; Castro and Scartascini, 2015).

On the other hand, the issue of non-compliance activities regarding to the indirect tax had caused to a major wasted to the governments not just in term of the fiscal side, but also non-financial aspects like embargo, quotas and product quality. However, the studies on indirect tax non-compliance have received very little attention between the legislators and researchers (Miskama et al., 2015). The indirect tax noncompliance became as prime concern of the most countries around the globe (Sinnasamy and Zainol, 2017). The sales tax system enhances the impact of an efficient the spending of government on the economic growth of 115 countries (Chan et al., 2017). Therefore, such as any tax, the sales tax is vulnerable to fraud and evasion. Further, sales tax non-compliance is also a topic of independent concern, since, in recent decades, it has replaced other shapes of sales tax in numerous countries and continues to attract new converts ( Alshira'h et al., 2018, Das-Gupta and Gang, 2003). Sales tax, or as called in many countries, such as Britain, the USA and France, value added tax (VAT), was introduced for the first time in France in 1954, where VAT was considered as a type of consumption tax on goods that was imposed at the production level (Adams and Webley, 2001). Sales tax is seen as crucial in providing the tax revenue base for governments, particularly in developing states, due to their wide coverage (Faridy et al., 2016; George and Reddy, 2015).

Jordanian government undertakes various fiscal measures to maximize domestic throughout the past few decades but according to the annual reports, the country still faces a sharp increase in net public debt and fiscal deficit brought about by the increase in the rate of tax non-compliance (Alshira'h and AbdulJabbar, 2019b). Therefore, the tax compliance problems have become a national concern; it is a significant problem that affects Jordanian economy, which is widespread in Jordan (Alshira'h, 2019, Alasfour, 2017; Qtish, 2015). Taxpayers in Jordan generally avoid from paying tax by several ways (Alshir'ah et al., 2016). However, the cases of tax non-compliance related to sales tax more than the income tax (Nsour, 2014). Estimated of shadow economic in Jordan increased considerably during the period from 2005-2010 as shown in the following Table 1.

Table 1. Shadow Economy in Jordan by Types of Tax, 2005-2010. (JD million)

\begin{tabular}{lcccccc}
\hline \multirow{2}{*}{ Indicators } & \multicolumn{4}{c}{ Year } \\
\cline { 2 - 7 } & $\mathbf{2 0 0 5}$ & $\mathbf{2 0 0 6}$ & $\mathbf{2 0 0 7}$ & $\mathbf{2 0 0 8}$ & $\mathbf{2 0 0 9}$ & $\mathbf{2 0 1 0}$ \\
\hline \multirow{2}{*}{ Indirect Tax } & $1,840.5$ & $2,214.6$ & $2,878.7$ & $3,804.3$ & $4,054.5$ & $4,634.8$ \\
\hline \multirow{2}{*}{ Direct tax } & $76.1 \%$ & $73 \%$ & $72.9 \%$ & $73.5 \%$ & $69.6 \%$ & $76.2 \%$ \\
\hline Shadow Economic & 578.4 & 821 & $1,068.7$ & $1,371.7$ & $1,772.3$ & $1,451.2$ \\
\hline Shadow Economic of GDP & $23.9 \%$ & $27 \%$ & $27.1 \%$ & $26.5 \%$ & $30.4 \%$ & $23.8 \%$ \\
\hline
\end{tabular}

Source: Alkhdour (2011)

Table 1 above illustrates the major source of shadow economic which was generated from indirect tax. For the same period the contribution of indirect tax in shadow economic increased from JD 1,840.5 in 2005 to JD 4,634.8 in 2010, represented by $76 \%$ of the total shadow economic. Earlier, the shadow economy increased after the imposition of sales tax, it increased from $12.5 \%$ in 1993 to $22.1 \%$ in 2010 of GDP, this is as a result of an increase in the sales tax rate from $10 \%$ to $13 \%$ in 1999 and to $16 \%$ in 2004 (Alkhdour, 2011). Recently, the estimates of shadow economy to $25 \%$ in 2015 of GDP (Jordanian Economic 
and Social Council [JESC], 2014). Furthermore, taxes are deemed to be the primary government source of revenue in Jordan (Al-Naimat, 2013). The role of taxes in the country's development has been emphasized after the sharp economic crisis in 1988, and ever since the adoption of the first International Monetary Fund (IMF) economic adjustment program in 1989, the Jordanian government has tried its best to make reforms when it comes to tax system efficiency, increased tax revenue, and reduced dependence on nontax revenue (Alkhdour, 2011). Jordan has very limited economic resources, experiencing a chronic budget deficit, and, hence, tax is a very important resource for financing all social and economics projects (Shahateet et al., 2014).

\section{Literature review}

\subsection{Tax compliance}

Taxes are critical elements of the total domestic revenue in the developed and developing countries. Countries promote their economy by their heavy dependence on both types of taxes that are either direct or indirect (Tehulu and Dinberu, 2014; Vadde, 2014; Thananga et al., 2013). Tax compliance is a compulsory duty imposed on all people in corporates or as individuals. Therefore, all people are expected to voluntarily comply to tax law, but some people do not follow the tax law (Seidu et al., 2015; Kirchler et al., 2014). Hence, companies and individuals who do not comply to pay taxes are a critical challenge faced by the tax authorities (Jayawardane, 2015).

Andreoni et al. (1998) defined tax compliance as taxpayers' willingness to comply to tax laws in order to support the economy balance of the country. Another definition by Alm (1991) and Jackson and Milliron (1986) defined tax compliance as the reporting of all incomes and payments of all taxes by fulfilling the provisions of laws, regulations and court judgments. Tax compliance, tax avoidance, tax evasion, and tax fraud are used synonymously throughout tax compliance researches, with several researchers making a difference between tax evasion and tax avoidance (O'Shaughnessy, 2014). As for tax non-compliance, it takes either the form of tax evasion or tax avoidance, relying on the legality grade of taxpayers' business (illegal business or legal business) (Bătrâncea and Nichita, 2012; Likhovski, 2007). Regarding tax evasion, it involves illegal and intended business taken by institutions and individuals to lower their legally due tax commitments of under-reporting sales, income or wealth by exaggerating deductions, dispensations or loans or by failing to file suitable tax returns (Ritsatos, 2014).

In a short, tax non-compliance is a worldwide phenomenon; it imposes many economic costs and burdens on all governments. First, tax non-compliance leads unfairness between those who comply and those who do not comply by moving the tax burden to the first group, and thereby generating a motive for further non-comply (Feinstein, 1991). Second, it causes inadequacy in businesses' production, as they resort to stay invisible and small to facilitate non-compliance (Nur-Tegin, 2008). Third, tax non-compliance changes resources to non-productive activities like founding financial subsidiaries to cover up noncompliance (Slemrod, 2007). Finally, non-compliance probably retards the economic growth. Hence, the government's capacity to provide appropriate public goods, infrastructure, development of human capital, and development will fragile and weak (Johnson et al., 2000).

Given the importance of understanding tax compliance, several studies have focused on income tax compliance, whereas very limited studies have been conducted on sales tax compliance, which is also considered the most common and important in many countries in the world. It is important to note that the word 'tax compliance' in the current study refers to tax compliance in general. In the case of indirect taxation, such as sales tax, the specific term 'sales tax compliance' is used. Hence, sales tax non-compliance is a widespread phenomenon that involves the process of manipulating sales tax invoice and altering tax reports to achieve personal benefits, such as paying less sales tax, increasing earning and reducing a cost based on benefits obtained through evading taxes or depending on attitudes, beliefs and norms. Therefore, sales tax compliance is defined as a correct record of details on sales tax invoice, rather than being fraudulent in the details of tax invoice to pay less sales tax.

\subsection{Tax moral}

The morals of taxpayers are a hazy concept to be defined. Morals generally refer to the ethics, values or principles held by a person (Jackson and Milliorn, 1986). Hence, tax moral, tax ethics or tax honesty are 
defined as an intrinsic motivation to pay taxes arising from the moral obligation to pay taxes and the belief in contributing to the society by paying taxes (Cummings et al., 2009; Torgler and Schneider, 2009). This concept of moral values can aid in explaining why tax non-compliance deterrence based on the economic factors cannot clarify efficient high levels of tax compliance (Vythelingum et al., 2017; Loureiro, 2014). The moral behaviour is defined as an intrinsic motivation by moral principles and ethical value (Young et al., 2016). That is, morals are systems of principles of behaviour that are developed to supply orientation in social interactions or the relation between people's behaviour and are utilised to adjust and temperate the human affairs (Ho and Wong, 2008). Thus moral works can be explained by five dimensions, namely moral knowledge, socialization, autonomy, empathy, and moral judgment (Hogan, 1973).

In this regard, sales tax moral is considered an intrinsic motivation to pay sales taxes resulting from the ethics compliance to pay sales taxes and the strong belief in contributing to build one's nation. Richardson (2006) revealed that non-economic factors exercise the strongest effect on tax non-compliance in comparison with the economic ones, and moral values were found to be one of the most important factors across the 45 countries. Tax moral was defined as the moral principles or values individuals hold about paying taxes (Alm and Torgler, 2006). Considering the moral feelings, such as guilt and shame, would provide a satisfactory clarification about taxpayer's compliance behaviour (Martinez-Vazquez and Torgler, 2009). Guilt feelings, also referred to as tax moral, may contribute to reduce tax non-compliance (Torgler, 2007). However, moral values are considered a societal phenomenon that is hard to be explained (Torgler, 2002).

Alm and Torgler (2006) compared the levels of tax moral values between Spain and USA and found that moral values in USA are higher than Spain and other fourteen European countries (Alm and Torgler, 2004). According to Kaplan et al. (1997), tax compliance intentions are significantly higher among taxpayers who have a high moral reasoning in their decision. Therefore, tax moral may increase when the taxpayers perceive that the public goods and service provided by the government are equal to their tax payment. Tax moral may also increase through the participation of the taxpayers in the political and the governmental decisions, fair procedures, taxpayers' perceived fairness and friendliness of the tax department (Feld and Schneider, 2010). However, tax moral decreases when the taxpayers have low trust in their government and the tax authorities, and feel lack of respect by the tax authorities (Frey, 2003).

McKerchar et al. (2013) reported three main factors as significant for tax moral, namely moral basics and standards that define what suitable behaviour are for persons as portion of a social mass, the perceived inclusive justice of the tax system, and confidence in the state's institutions. Hence, moral values play a vital role in influencing the magnitude of the informal economy, whereby higher moral values cause less shadow economy (Loureiro, 2014; Torgler et al., 2010).

The prior studies found that tax moral has a positive relation with tax compliance behaviour, and increasing the tax moral leads to lower tax non-compliance and greater tax compliance (e.g., Lisi, 2015; Nabaweesi, 2013; Torgler et al., 2007; Witte and Woodbury, 1985). Similarly, Riahi-Belkaoui (2004) found that tax compliance has a positive relationship with tax moral principles. These moral values, as Torgler (2003) argued, are affected positively by trust in the government and the law system. In this regard, Leonardo (2011) and Cummings et al. (2009) reported that the quality of the public governance has a significant positive association with tax moral, whereby increasing the willingness to comply is related with a higher quality of the public governance. Therefore, democratic states showed a positive relationship between the democratic values and trust in the government and tax moral.

Therefore, moral of the taxpayers must be taken into account when examining the tax compliance behaviour, since it is one of the factors that could explain compliance behaviour levels that are higher than those expected through the economic theory (Christian and Alm, 2014). On the other hand, Blumenthal, Christian and Slemrod (2001) argued that the taxpayers who have tax moral have a higher tendency towards tax non-compliance. Similarly, Fellner et al. (2013) reported that the moral value does not lead to increasing the compliance. Ariel (2012) also revealed that the moral persuasion did not improve the tax compliance. In the context of sales tax, prior studies found that there are positive relationship between tax moral and sales tax compliance (Woodward and Tan, 2015; Webley et al., 2004).

On the basis of the above discussions, the relationship between tax moral and income tax compliance still needs further examinations to be confirmed. However, the majority of the researches on 
tax moral and tax compliance have focused on income tax, whereas sales tax compliance has received very limited interest. In addition, tax moral and tax compliance have been examined at the individual level, whereas SMEs' tax compliance with tax moral has been neglected. This is supported by Alm and McClellan (2012) who stated that the potential importance of firm tax moral has been ignored, perhaps because of the absence of firm-level information that would allow a firm's tax moral to be measured. Therefore, more studies are required to determine the relation between tax moral and sales tax compliance since tax moral is one of the main determinants of tax compliance behaviour. Also, to the best knowledge of the researcher, no study has been conducted on the relationship between tax moral and sales tax compliance behaviour of SMEs in the Middle East and Arab countries. Therefore, there is a need for more studies to be conducted on this relationship, especially in Jordan.

$\mathrm{H} 1$ : There is a positive relationship between tax moral and sales tax compliance among Jordanian SMES.

\section{Study model}

\begin{tabular}{|l|l|l|}
\hline Tax Moral & Sales Tax Compliance \\
\cline { 2 - 3 } & \\
\hline
\end{tabular}

Figure 1. Research Framework

\section{Methodology of research}

The current study adopts a quantitative approach to determine the tax moral affecting the sales tax compliance of SMEs in Jordan. The purpose of the quantitative approach is to predict, explain and control social phenomena (Wellington and Szczerbinski, 2007). A popular purpose of quantitative research is to test hypotheses or specific research questions (Zikmund et al., 2013). Additionally, it enables the researcher to concentrate on a particular issue, to pursue a rigorous method, and to generate valid conclusions (Sekaran, 2003). Collecting data through a self-administered questionnaire gives respondents personal space for replying to the questions of the questionnaire (McShane and Glinow, 2012). This method also gives researchers a chance to verbally clarify the significance of the study and can establish rapport and motivate respondent and provide careful explanations, when needed, regarding difficult, significant or sensitive questions. Thus, doubts can be clarified, and the anonymity of respondent is high (Sekaran and Bougie, 2016). Many prior studies used the self-administrated method in the context of taxation (e.g., Kamar, 2015; Mohdali and Pope, 2014).

This research concentrates on the effect of tax moral on sales tax compliance of SMEs. To achieve this purpose, this study focuses on SMEs in the Jordanian manufacturing sector as the population of this study. In this study, the study population comprises of the owner-managers of SMEs in Jordanian manufacturing sector obtained from the list of the Jordan Chamber of Industry (JCI) via an official application procedure, which provides a list of 17,849. The sample list contained the details of every SME in the manufacturing sector, such as name, phone number and email. Furthermore, any business in Jordan is required to register with the $\mathrm{JCl}$ to get a license to work. The researcher distributed 660 questionnaires to the SMEs respondents. After around three months, 221 (33.5\%) questionnaires were collected from SMEs. Based on Sekaran and Bougie (2016) a response rate of $30 \%$ and above is acceptable for a survey.

\section{Results}

\subsection{Measurement model}

In the PLS-SEM analysis, the first step is estimate the measurement model. The measurement model comprises the component of the measurement, which determining the loadings for each item, composite reliability (CR), and the average variance extracted (AVE). Table 2 present the factor loadings for the items, composite reliability and (AVE). These items were then used for further analysis in PLS-SEM. Based on Table2, sales tax compliance had four items (STC6, STC7, STC10, STC11), which were loaded less than cutoff value of 0.40 according to Hair et al. (2014a), thus this items was deleted. Tax moral had five items that loaded below than cut-off value, such as (TM1, TM6, TM7, TM9, TM10), thus these items were deleted 
from this factor. Table 2 also shows the CA values for variables; the CR values of the variables loaded from 0.842 to 0.883 , the values of the CR should be equal to or exceed 0.70 (Hair et al., 2014b).

Table 2. Average value and outer loading every indicator, CR and AVE

\begin{tabular}{ccccc}
\hline Latent construct & Items & Loading & CR & AVE \\
\hline & STC1 & 0.818 & 0.883 & 0.519 \\
& STC2 & 0.819 & & \\
Sales tax compliance (STC) & STC3 & 0.726 & & \\
& STC4 & 0.695 & & \\
& STC5 & 0.665 & & \\
& STC8 & 0.643 & & \\
& STC9 & 0.659 & & \\
\hline & & 0.663 & 0.842 & 0.517 \\
Tax moral (TM) & & 0.782 & & \\
& & 0.747 & & \\
& & 0.673 & & \\
& & 0.693 & & \\
\hline
\end{tabular}

As a rule of thumb, the AVE of every latent variable should be higher than 0.50 for establishing adequate convergent validity (Hair et al., 2014b). In the current study, Table 2 shows the values of AVE ranged between 0.517 and 0.520 indicating an adequate convergent validity. Thus, the conclusion can be made that the internal consistency reliability of the measures and convergent validity was verified and confirmed.

\subsection{Structural model}

After analysing and assessing the measurement model, the following step in the PLS modelling is to test the inner model (structural model). Typically, there are four requirements to assess the structure model comprising: 1 ) the $R^{2}$ values, effect size $\left(f^{2}\right)$, predictive relevance $\left(Q^{2}\right)$ of the model, and path coefficient $(\beta)$ to test the study hypotheses (Hair et al., 2014b; Henseler et al., 2009). Additionally, the Goodness of Fit (GoF) that Tenenhaus et al (2005) suggested was used. Finally, bootstrapping was employed to examine the significance level of the hypothesis in the study model. The results of the analysis are summarized in Table 3.

Table 3. Structural Model PLS-SEM

\begin{tabular}{cccccc}
\hline Hypothesis No. & Relationship & Path coefficient & T -Value & P - Value & Decision \\
\hline H1 & TM $>$ STC & 0.197 & 2.865 & $0.004^{*}$ & Supported \\
\hline $\mathbf{R}^{2}$ sales tax compliance $=$ & $0.256 ; \mathbf{Q}^{2}$ sales tax compliance $=0.095$ & & & \\
\hline
\end{tabular}

Note: Significant at $* p<0.01$ (One-Tailed).

Based on Table 3, The result provided support for $\mathrm{H1}(\beta=0.197, \mathrm{t}=2.865, \mathrm{p}<0.01)$. This signifies that a significant positive relationship exists between (TM) tax moral and sales tax compliance (STC).

\subsection{Goodness of Fit of the Model}

PLS has only a single measure goodness of fit (GoF), which Tenenhaus et al (2005) proposed. A global fit measure (GoF) for PLS path modelling can be defined as the geometric mean of the average communality and average $\mathrm{R}^{2}$ for the endogenous constructs. The main purpose of the goodness of fit measure is to explain the variance extracted by both the measurement model and structure model (Chin, 2010). The GoF can be calculated by the following formula.

$$
\text { GoF }=\sqrt{\left(\overline{R^{2}} \times \overline{A V E}\right)}
$$

In this study, the GoF value of the model was 0.446 , which has been attained as follows:

$\mathrm{GOF}=\sqrt{ } 0.256 \times 0.519=0.263$ 
In comparing the GoF value of this study with the threshold values of GoF that Wetzels et al. (2009) recommends (less than 0.1 represents no fit, between 0.1-0.25 represents small, between 0.25-0.36 represents medium, and greater than 0.36 represents large), the conclusion can be made that the model GoF was medium indicating a sufficient of the global PLS model validity.

\section{Conclusions and recommendations}

Tax moral is one of the major factors influencing tax compliance (Jackson, Million, 1986). It is a moral commitment to pay tax and contribute to generating revenue for the nation to provide welfare of the society (Torgler, 2003). Evidence points out that, at the aggregate level, states with great levels of tax morals have smaller informal economies (Halla, 2012; Torgler and Schneider, 2009), and taxpayers with a higher level of tax morals are more likely to comply with paying taxes (Blanthorne and Kaplan, 2008; Wenzel, 2005). Hence, hypothesis (H1) shows that association between tax moral and sales tax compliance was positive and significant. The result indicates that tax moral has a significant positive influence on sales tax compliance. In other words, the higher ethics of owner-managers ensures a strong tendency towards sales tax compliance. The finding is consistent with socio-psychological approach predictions (Kohlberg, 1969). Past literature supports these findings, and several researchers have found out a significant positive relationship between tax moral and sales tax compliance of SMEs (Woodward and Tan, 2015; Webley et al., 2004). Nonetheless, previous studies on this specific area remain rare. In general, this result is also in accordance with previous studies related to tax moral and income tax compliance as tax behaviour (e.g., Lisi, 2015; Loureiro, 2014; Nabaweesi, 2013; Torgler et al., 2010; Torgler et al., 2007).

The result in the current study also indicates that the effect of tax morals on sales tax compliance depends mainly on the moral principles or values that individuals hold about paying taxes (Torgler and Murphy, 2004). Even though tax non-compliance is ethically acceptable in Jordan under some circumstances, and indeed, based on cultural differences (Alasfour et al., 2016). However, tax compliance has a positive relationship with tax moral principles in Jordan (AL-Shawawreh and Al-Smirat, 2016). Therefore, adequate tax moral for SMEs owner-managers may significantly and positively influence the sales tax compliance decision. The owner-managers is considered the primary decision maker for a SMEs, and his/her ethics determines the level of sales tax compliance. Therefore, tax moral clearly plays a key role in promoting sales tax compliance. The current study model was capable to explain $25.6 \%$ of the total variance in sales tax compliance, which means that there are other variables that could also significantly explain the variance in sales tax compliance. In other words, the remaining $74.4 \%$ of the variance in sales tax compliance could be explained by other latent variables. Therefore, future study is needed to consider other possible constructs that could impact the sales tax compliance such tax knowledge, religion, external audit, gender of tax auditor, and tax service quality.

\section{References}

1. Abdul-Jabbar, H., \& Pope, J. (2008). Exploring the relationship between tax compliance costs and compliance issues in Malaysia. Journal of Applied Law and Policy, 1(1), 1-20.

2. Adams, C., \& Webley, P. (2001). Small business owners attitudes on VAT compliance in the UK. Journal of Economic Psychology, 22(1), 195-216.

3. Al-Naimat, S. M. A. (2013). Theoretical and analytical study of tax law in Jordan according to the: income tax and sales tax and its relationship with revenues and tax evasion. International Journal of Financial Research, 4(3), 107-126. https://doi.org/10.5430/ijfr.v4n3p107

4. Al-ttaffi, L. H. A., \& Abdul-jabbar, H. (2015). Does muslim view on tax influence compliance behaviour? In International Conference on Accounting Studies (ICAS) 2015 17-20 August 2015, Johor Bahru, Johor, Malaysia.

5. Alasfour, F., Samy, M., \& Bampton, R. (2016). The Determinants of Tax Morale and Tax Compliance: Evidence from Jordan, 125-171. https://doi.org/10.1108/S1058-749720160000023005

6. Alasfour, F. (2017). Costs of distrust: The virtuous cycle of tax compliance in Jordan. Journal of Business Ethics, 1-16.

7. AL-Shawawreh, T. B., \& AL-Smirat, B. Y. (2016). Economic Effects of Tax Evasion on Jordanian Economy. International Journal of Economics and Finance, 8(7), 344. 
8. Andreoni, J., Erard, B., \& Feinstein, J. (1998). Tax compliance. Journal of Economic Literature, 36(2), 818-860

9. Awang N., Abdullah W.F.W., Tahir N.M., Rahim N.A. (2018). An insight on the impact of norms and ethics on tax compliance. In Said R., Mohd Sidek N., Azhar Z., Anuar Kamarudin K. (eds). State-of-theArt Theories and Empirical Evidence (pp. 41-48). Springer, Singapore.

10. Alkhdour, R. (2011). Estimating the shadow economy in Jordan: causes, consequences, and policy implications. (Unpublished doctoral thesis), Colorado State University.

11. Alm, J., Clark, J., \& Leibel, K. (2016). Enforcement, socioeconomic diversity, and tax filing compliance in the United States. Southern Economic Journal, 82(3), 725-747. https://doi.org/10.1002/ soej.12106

12. Alm, J. \& B. Torgler. (2006). Culture differences and tax morale in the United States and in Europe. Journal of Economic Psychology, 27, 224-246.

13. Alm, J. (1991). A perspective on the experimental analysis of taxpayer reporting. The Accounting Review, 66(3), 577-593.

14. Alm, J., \& McClellan, C. (2012). Tax morale and tax compliance from the firm's perspective. Kyklos, 65(1), 1-17.

15. Alm, J., \& Torgler, B. (2004). Estimating the determinants of tax morale. Proceedings Annual Conference on Taxation and Minutes of the Annual Meeting of the National Tax Association, 97, 269-274.

16. Alm, J., \& Torgler, B. (2006). Culture differences and tax morale in the United States and in Europe. Journal of Economic Psychology, 27, 224-246. https://doi.org/10.1016/j.joep.2005.09.002.

17. Alshir'ah, A. F., Abdul-Jabbar, H., \& Samsudin, R. S. (2016). Determinants of sales tax compliance in small and medium enterprises in Jordan : A call for empirical research. World Journal of Management and Behavioral Studies, 4(1), 41-46.

18. Alshira'h, A. F., Abdul-Jabbar, H., \& Samsudin, R. S. (2018). Sales tax compliance model for the Jordanian small and medium enterprises research. Journal of Advanced Research in Social and Behavioural Sciences, 10(2), 115-130.

19. Alshira'h, A. F., \& Abdul-Jabbar, H. (2019a). The effect of tax fairness on sales tax compliance among Jordanian manufacturing SMEs. Academy of Accounting and Financial Studies Journal, 23(2), 1-12.

20. Alshira'h, A. F., \& Abdul-Jabbar, H. (2019b). A conceptual model of sales tax compliance among Jordanian SMEs and its implications for future research. International Journal of Economics and Finance, 11(5), 1-14.

21. Alshira'h, A. F. (2019). The Effect of peer influence on sales tax compliance among Jordanian SMEs. International Journal of Academic Research in Business and Social Sciences, 9(3), 710-721.

22. Arachi, G., \& Santoro, A. (2007). Tax enforcement for SMEs: lessons from the Italian experience ? eJournal of Tax Research, 5(2), 225-243.

23. Ariel, B. (2012). Deterrence and moral persuasion effects on corporate tax compliance: findings from a randomized controlled trial. Criminology, 50(1), 27-69. https://doi.org/10.1111/j.17459125.2011.00256.x

24. Asrinanda, Y. D. (2018). The Effect of Tax Knowledge, Self-Assessment System, and Tax Awareness on Taxpayer Compliance. International Journal of Academic Research in Business and Social Sciences, 8(10), 539-550.

25. Blumenthal, M., \& Christian, C. (2001). Do normative appeals affect tax compliance? evidence from a controlled experiment in Minnesota. National Tax Journal, 54(1), 125-138.

26. Blanthorne, C., \& Kaplan, S. (2008). An egocentric model of the relations among the opportunity to underreport, social norms, ethical beliefs, and underreporting behavior. Accounting, Organizations and Society, 33(7-8), 684-703.

27. Chin, W. W. (2010). How to write up and report PLS analyses. In: Vinzi, V.E., Chin, W. W., Henseler, J. \& Wang, H. (Eds.), Handbook of Partial Least Squares, first ed. Springer, Berlin, pp. 655-690.

28. Castro, L., \& Scartascini, C. (2015). Tax compliance and enforcement in the pampas evidence from a field experiment. Journal of Economic Behavior \& Organization, 116, 65-82. https://doi.org/ 10.1016/j.jebo.2015.04.002 
29. Chan, S.-G., Ramly, Z., \& Karim, M. Z. A. (2017). Government Spending Efficiency on Economic Growth: Roles of Value-added Tax. Global Economic Review, 3873(February), 1-27. https://doi.org/ 10.1080/1226508X.2017.1292857

30. Christian, R., \& Alm, J. (2014). Empathy, sympathy, and tax compliance. Journal of Economic Psychology, 40(2), 62-82. https://doi.org/10.1016/j.joep.2012.10.001.

31. Cummings, R. G., Martinez-Vazquez, J., McKee, M., \& Torgler, B. (2008). Tax morale affects tax compliance: evidence from surveys and an artefactual field experiment. Journal of Economic Behavior \& Organization, 70(3), 447-457. https://doi.org/10.1016/j.jebo.2008.02.010

32. Das-Gupta, A., \& Gang, I. (2003). Value added tax evasion, auditing and transactions matching. Inl. Maclarn(2003) Institutional elements of tax design and reform. The World Bank, Washington, USA.

33. Devos, K. (2008). Tax evasion behaviour and demographic factors : An exploratory study in Australia. Revenue Law Journal, 18(1), 1-45.

34. Doerrenberg, P., Duncan, D., Fuest, C., \& Peichl, A. (2014). Nice guys finish last : Do honest taxpayers face higher tax rates. KYKLOS, 67(1), 29-53.

35. Faridy, N., Freudenberg, B., Sarker, T., \& Copp, R. (2016). The hidden compliance cost of VAT: An exploration of psychological and corruption costs of VAT in a developing country. eJournal of Tax Research, 14(1), 166-205.

36. Feld, L. P., \& Schneider, F. (2010). Survey on the Shadow Economy and Undeclared Earnings in OECD Countries. German Economic Review, 11(2), 109-149. https://doi.org/10.1111/j.1468-0475.2010. 00509.x

37. Fellner, G., Sausgruber, R., \& Traxler, C. (2013). Testing enforcement strategies in the field: Threat, moral appeal and social information. Journal of the European Economic Association, 11(3), 634-660. https://doi.org/10.1111/jeea.12013.

38. Finocchiaro, M., \& Ilde, C. (2014). Tax compliance under horizontal and vertical equity conditions: An experimental approach. Intarnational Tax Public Finance, 21(4), 560-577. https://doi.org/ $10.1007 / \mathrm{s} 10797-014-9320-5$

39. Frey, B. (2003). Deterrence and tax morale in the European Union. European Review, 11(3), 385406. https://doi.org/10.1017/S1062798703000346.

40. Frey, B., \& Torgler, B. (2007). Taxation and conditional cooperation. Journal of Comparative Economics, 35, 136-159. https://doi.org/10.2139/ssrn.662083.

41. Feinstein, J. S. (1991). An econometric analysis of income tax evasion and its detection. The RAND Journal of Economics, 22(1), 14-35.

42. Jackson, B. R., \& Milliron, C. V. (1986). Tax compliance research: Findings, problems and prospects. Journal of Accounting Literature, 5, 125-165.

43. Johnson, C., Masclet, D., \& Montmarquette, C. (2010). The effect of perfect monitoring of matched income on sales tax compliance: An experimental investigation. National Tax Journal, 63(1), 121148.

44. Jordan Economic and Social Council. (2014). Tax evasion in Jordan: causes, ways. www.esc.jo

45. Hair Jr, J. F., Hult, G. T. M., Ringle, C., \& Sarstedt, M. (2014b). A primer on partial least squares structural equation modeling (PLS-SEM). Sage Publications. UK.

46. Hair Jr, J., Sarstedt, M., Hopkins, L., \& G. Kuppelwieser, V. (2014a). Partial least squares structural equation modeling (PLS-SEM) An emerging tool in business research. European Business Review, 26(2), 106-121.

47. Halla, M. (2012). Tax morale and compliance behavior: First evidence on a causal link. The $B E$ Journal of Economic Analysis \& Policy, 12(1).

48. Henseler, J., Ringle, C. M., \& Sinkovics, R. R. (2009). The Use of Partial Least Squares Path Modeling in International Marketing. In New challenges to international marketing (pp. 277-319). Emerald Group Publishing Limited.

49. Ho, D., \& Wong, B. (2008). Issues on compliance and ethics in taxation: what do we know? Journal of Financial Crime, 15(4), 369-382. https://doi.org/10.1108/13590790810907218.

50. Hogan, R. (1973). Moral conduct and moral character: a psychological perspective. American Psychological Assoclation, 79(4), 217-232. https://doi.org/10.1037/h0033956. 
51. Isa, K. M. (2012). Corporate tax payers' compliance variables under the self-assessment system in Malaysia : A mixed methods approach. (Unpublished doctoral thesis), Curtin University.

52. Jayawardane, D. (2015). Psychological factors affect tax compliance- a review paper. Internatioanl Journal Of Arts and Commerce, 4(6), 131-141.

53. JESC. (2014). Tax evasion in Jordan: causes, ways.www.esc.jo.

54. Kamleitner, B., Korunka, C., \& Kirchler, E. (2012). Tax compliance of small business owners. International Journal of Entrepreneurial Behaviour \& Research, 18(3), 330-351. https://doi.org/10.1108/ 13552551211227710

55. Kamar, I. K. (2015). Effects of government taxation policy on sales revenue of SME in Uasin Isaac Kipchirchir Kamar. International Journal of Business and Management Invention, 4(2), 29-40.

56. Kaplan, S. E., Newberry, K. J., \& J. Reckers, P. M. (1997). The effect of moral reasoning and educational communications on tax evasion intentions. The Journal of the American Taxation Association, 19(2), 38-54.

57. Kohlberg, L. (1969). Stages and sequences: The cognitive development approch to socialisation. In D. Gosin, Handbook of Socialisation theory and Research. Chicago: Rand McNell

58. Kirchler, E., Kogler, C., \& Muehlbacher, S. (2014). Cooperative tax compliance: From deterrence to deference. Current Directions in Psychological Science, 23(2), 87-92. https://doi.org/10.1177/ 0963721413516975

59. Larissa-Margareta, B., \& Ramona-Anca, N. (2012). A neuroeconomic approach of tax behavior. Annals of Faculty of Economics, 1(1), 649-654. Retrieved from http://search.ebscohost.com/login.aspx? direct $=$ true $\& \mathrm{db}=\mathrm{bth} \& \mathrm{AN}=86068800 \&$ site $=$ ehost-live

60. Leonardo, G. (2011). Politics and tax morale. The role of trust, values, and beliefs, in shaping individual attitudes towards tax compliance. (Unpublished doctoral thesis), Georgia State University.

61. Likhovski, A. (2007). Training in citizenship: Tax compliance and modernity. Law \& Social Inquiry, 32(3), 665-700. https://doi.org/10.1111/j.1747-4469.2007.00073.x.

62. Lisi, G. (2015). Tax morale, tax compliance and the optimal tax policy. Economic Analysis and Policy, 45, 27-32. https://doi.org/10.1016/j.eap.2014.12.004.

63. Loureiro, J. (2014). Behavioural economics and tax compliance. The role of identifiability, geographical distance and social norms on tax compliance: An experimental study. (Unpublished masrter thesis), Economia E Gestao Universty. Retrieved from http://repositorio-aberto.up.pt/handle/10216/ 77194.

64. McShane, S. L., \& Glinow, M. A. V. (2012). Human Behavior in Organization. Philippines.

65. Mohdali, R., \& Pope, J. (2014). The influence of religiosity on taxpayers' compliance attitudes: Empirical evidence from a mixed-methods study in Malaysia. Accounting Research Journal, 27(1), 71-91.

66. Martinez-Vazquez, J., \& Torgler, B. (2009). The evolution of tax morale in modern Spain. Journal of Economic Issues, 43(1), 1-28. https://doi.org/10.2753/JEI0021-3624430101

67. Mascagni, G., Moore, M., \& Mccluskey, R. (2014). Tax revenue mobilisation in developing countries: issues and challenges (Working Paper). European Parliament, Directorate-General for External Policies of the Union.

68. McKerchar, M., Bloomquist, K., \& Pope, J. (2013). Indicators of tax morale: An exploratory study. eJournal of Tax Research, 11(1), 5-22.

69. McKerchar, M., \& Evans, C. (2009). Sustaining growth in developing economies through improved taxpayer compliance: challenges for policy makers and revenue authorities. eJournal of Tax Research, 7(2), 171-201.

70. Miskama, M., Noorb, R. M., Omarc, N., \& Abd Aziz, R. (2015). Determinants of tax evasion on imported vehicles.

71. Nabaweesi, J. (2013). Tax morale and tax compliance among small business enterprises in Uganda. Research Journal of Economics \& Businrss Studies, 2(11), 67-74.

72. Nar, M. (2015). The effects of behavioral economics on tax amnesty. International Journal of Economics and Financial Issues, 5(2), 580-589.

73. Ndekwa, A. G. (2014). Factors for improving tax compliance among small and medium enteprises in Tanzani. The International Journal of Business \& Management, 2(10), 285-290. 
74. Nsour, M. (2014). Tax evasion in Jordan: Causes, means and size. The Jordan Times Newspaper, 3 June, retrieved from: Jordantimes.com/tax- evasion-in-Jordan--causes-means-and-size. Accessed 24 March 2017. https://doi.org/10.16953/deusbed.74839.

75. Nur-Tegin, K. D. (2008). Determinants of business tax compliance. The BE Journal of Economic Analysis \& Policy, 8(1), 1-28.

76. O'Shaughnessy, D. (2014). Tax compliance determinants: A proposed model for cross-country analysis. (Unpublished doctoral thesis), University of Taxas at El Paso. Retrieved from http://digitalcommons.utep.edu/dissertations/AAI3636430/

77. Obadina, D. A. (2016). Confronting the problem of cross-border tax evasion in an era of greater global transparency of tax relevant information: the case of Nigeria. Journal of Money Laundering Control, 19(4), 1-34. https://doi.org/http://dx.doi.org/10.1108/09564230910978511

78. Obara, L. C., \& Nangih, E. (2017). Tax Compliance Barriers and Internally Generated Revenue in Nigeria: Empirical from Small and Medium Enterprises in Portharcourt Metropolis. International Journal of Academic Research in Accounting, Finance and Management Sciences, 7(4), 169-176.

79. Palil, M. R. (2005). Does tax knowledge matters in self-assessment systems? Evidence from Malaysia. Journal of American Academy of Business, Cambridge, 6(2), 80-84.

80. Perabavathi, S., \& Zainol, B. (2017). The Relationship between Tax Rate, Penalty Rate, Tax Fairness and Excise Duty Non-, 11001.

81. Pope, J., \& Abdul-Jabbar, H. (2008). Small and medium-sized enterprises and tax compliance burden in Malaysia: Issues and challenges for tax administration. Small Enterprise Research, 16(1), 47-60. https://doi.org/10.5172/ser.16.1.47

82. Prichard, W. (2010). Taxation and state building: Towards governance focused tax reform agenda (Working Paper No. 341). Institute of Development Studies at the University of Sussex Brighton BN1 9RE UK, 01-55. https://doi.org/10.1111/j.2040-0209.2010.00341_2.x.

83. Puspitasari, E., \& Meiranto, W. (2014). Motivational postures in tax compliance decisions: experimental studies. International Journal of Business, Economics and Law, 5(1), 100-110

84. Qtish, A. M. (2015). The impact of the merger of income tax department with sales tax department with their associated accounting and legal policies in the reduction of tax evasion. Research Journal of Finance and Accounting, 6(24), 97-108.

85. Radzi, N. Z. M., \& Ariffin, Z. Z. (2016). The moderating effect of honesty on tax non-compliance behaviour. International Information Institute, 19(8), 3101-3106.

86. Randlane, K. (2016). Tax Compliance as a system: Mapping the field. 10.1016/j.ecosys.2016. 12.004, 39(7), 515-525. https://doi.org/10.1080/01900692.2015.1028636

87. Raza, S. H., \& Naqvi, S. M. A. (2016). Impact of Tax Evasion on Total Tax in Pakistan. International Journal of Academic Research in Business and Social Sciences, 6(11), 730-739.

88. Riahi-Belkaoui, A. (2004). Relationship between tax compliance internationally and selected determinants of tax morale. Journal of International Accounting, Auditing and Taxation, 13(2), 135-143. https://doi.org/10.1016/j.intaccaudtax.2004.09.001.

89. Ritsatos, T. (2014). Tax evasion and compliance: from the neo classical paradigm to behavioural economics, a review. Journal of Accounting \& Organizational Change, 10(2), 244-262. https://doi.org/ 10.1108/JAOC-07-2012-0059.

90. Sawyer, A. (2014). Comparing the Swiss and United Kingdom cooperation agreements with their respective agreements under the foreign account tax compliance Act. eJournal of Tax Research, 12(2), 285318.

91. Seidu, A. N., Abdul, I. W., \& Sebil, C. (2015). Modelling the causes of tax default among small and medium scale enterprises (SMEs) in the tamale metropolis of Ghan. European Scientific Journal January, 11(1), 155-168.

92. Sekaran, U. (2003). Research methods for business. A skill building approach. (Fourth edition). Wiley.

93. Sekaran, U., \& Bougie, R. (2016). Research methods for business: A skill building approach. John Wiley \& Sons. 
94. Slemrod, J. B. (2007). Cheating ourselves: The economics of tax evasion. The Journal of Economic Perspectives 21, 25-48

95. Shahateet, M. I., Al-Habashneh, F., \& Al-Majali, K. A. (2014). Budget deficit and external debt in jordan: causality and co-integration analysis. International Journal of Economics and Finance, 6(8), 268-277. https://doi.org/10.5539/ijef.v6n8p268

96. Strader, J., \& Fogliasso, C. (1989). An investigation of some factors affecting taxpayer noncompliance. Accounting \& Business Research, 20(77), 39-46. https://doi.org/10.1080/00014788.1989. 9729393

97. Swistak, A. (2015). Tax penalties in SME tax compliance. Financial Theory and Practice, 40(1), 129-147. https://doi.org/10.3326/fintp.40.1.4

98. Tehulu, T. A., \& Dinberu, Y. D. (2014). Determinants of tax compliance behavior in Ethiopia: The case of bahir dar city taxpayers. Journal of Economics and Sustainable Development, 5(15), 268-274.

99. Tenenhaus, M., Vinzi, V. E., Chatelin, Y. M., \& Lauro, C. (2005). PLS path modeling. Computational statistics \& data analysis, 48(1), 159-205.

100. Thananga, A. G., Wanyoike, D. M., \& Wagoki, A. J. (2013). Factors affecting compliance on rental income tax policy by landlords in Nakuru municipality. Journal of Agriculture and Environmental Sciences, 2(1), 26-38.

101. Torgler, B. (2002). Speaking to theorists and searching for facts: Tax morale and tax compliance in experiments. Journal of Economic Surveys, 16(5), 657-683. https://doi.org/10.1111/1467-6419.00185

102. Torgler, B. (2003). Tax morale, rule-governed behaviour and trust. Constitutional Political Economy, 14(2), 119-140.

103. Torgler, B., Schaffner, M., \& Macintyre, A. (2007). Tax compliance, tax morale, and governance quality. Andrew Young School of Policy Studies international conference. Altanta: Georgia State University.

104. Torgler, B., \& Schaltegger, C. a. (2005). Tax morale and fiscal policy (Unpublished Working Paper No. 1748). Center for Research in Economics, Management and the Arts.

105. Torgler, B., \& Schneider, F. (2009). The impact of tax morale and institutional quality on the shadow economy. Journal of Economic Psychology, 30(2), 228-245. https://doi.org/10.1016/ j.joep.2008.08.004.

106. Torgler, B., Schneider, F., \& Schaltegger, C. a. (2010). Local autonomy, tax morale, and the shadow economy. Public Choice, 144(1), 293-321. https://doi.org/10.1007/s11127-009-9520-1.

107. Torgler, B., \& Murphy, K. (2004). Tax morale in Australia: What shapes it and has it changed over time. J. Austl. Tax'n, 7, 298.

108. Vadde, S. (2014). Compliance and noncompliance behavior of business profit taxpayers' towards the tax system: A case study of Mekelle city. Scholars Journal of Economics, Business and Management, 1(10), 525-531. Retrieved from http://saspjournals.com/sjebm.

109. Vadde, S., \& Gundarapu, S. (2012). Factors that influence rental tax payers' compliance with tax system: An empirical study of Mekelle city, Ethiopia. Journal of Arts, Science \& Commerce, 3(4), 41-49.

110. Vythelingum, P., Soondram, H., \& Jugurnath, B. (2017). An assessment of tax morale among Mauritian taxpayers, 9(1), 1-10. https://doi.org/10.5897/JAT2016.0224.

111. Webley, P., Adams, C., \& Elffers, H. (2002). VAT compliance in the United Kindom (Working Paper No. 41). Centre for Tax System Integrity Research School of Social Sciences, Australian National University.

112. Woodward, L., \& Tan, L. M. (2015). Small business owners' attitudes toward GST compliance : a preliminary study. Australian Tax Forum, 3(2), 517-550.

113. Wellington, J., \& Szczerbinski, M. (2007). Research methods for the social sciences. A\&C Black.

114. Wenzel, M. (2005). Motivation or rationalisation? Causal relations between ethics, norms and tax compliance. Journal of Economic Psychology, 26(4), 491-508.

115. Wetzels, M., Odekerken-Schröder, G., \& Van Oppen, C. (2009). Using PLS path modeling for assessing hierarchical construct models: Guidelines and empirical illustration. MIS quarterly, 177-195.

116. Witte, A. D., \& Woodbury, D. F. (1985). The effect of tax laws and tax administration on tax compliance: The case of the US individual income tax. National Tax Journal, 38(1), 1-13. 
117. Young, A., Lei, L., Wong, B., \& Kwok, B. (2016). Individual tax compliance in China: A review. International Journal of Law and Management, 58(5), 1-12. Retrieved from http://cataleg.upf.edu/record= b1313096 S11*cat.

118. Zikmund, W. G., Babin, B. J., Carr, J. C., \& Griffin, M. (2013). Business research methods. Cengage Learning. 